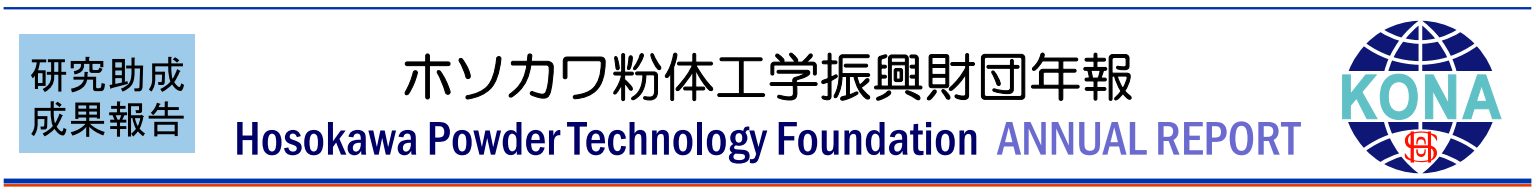

13112

\title{
超音波定在波音場の形成条件による懸濁粒子の挙動変化 \\ Variation of Suspending Particle Motion for \\ Condition of Ultrasonic Standing Wave
}

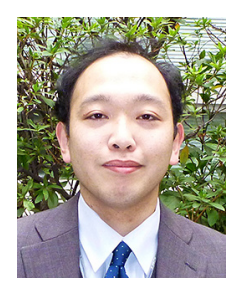

\author{
研究代表者 Research leader：河府 賢治 Kenji KOFU \\ 日本大学理工学部 助教 \\ College of Science \& Technology, Nihon University, Assistant Professor \\ E-mail: kofu@mech.cst.nihon-u.ac.jp
}

\begin{abstract}
抄録
超音波定在波を利用した気相中の粒子挙動制御に関し，粒子挙動を実験で確認すると共に計算を行 い, 計算の妥当性の確認を行った.実験とシミュレーションにおいて超音波振動による板間に生ず る定在波音場が同様の結果が得られた。しかし, 水平な流路に定在波音場を形成し, 粒子挙動を調 ベた結果, 実験, シミュレーションともに重力が支配的となり音圧を $2 \mathrm{kPa}$ 程度まで高めないと挙 動に変化が現れなかった，そこで, 主流方向と重力方向を同一とし, 音圧による挙動変化を調べた。 その結果, $500 \mu \mathrm{m}$ の発砲スチロールは節の位置に移動したが, $8,57 \mu \mathrm{m}$ 程度の白色溶融アルミナ では音圧により節に集めることが難しいことも明らかとなった。また空気中を懸濁する微小粒子は 音圧分布により生ずる音響流の影響を受けること, 振動モードを変えることで音圧を高めなくても 粒子挙動を制御できることも示された.
\end{abstract}

\begin{abstract}
The purpose of this research is to control the particles motion in the ultrasonic standing wave. The results of simulation have been compared with experiment in order to examine the possibility of particles motion control in the air. Simulations have corresponded with experiments on acoustic pressure distribution and particle motion. However particle motion control was impossible in this experiment because radiation pressure acting on particle was poor and gravity force dominates. Then, simulation showed that the particle motion is changed if the sound pressure is increased. This means it is possible to control the particles motion by ultrasonic if high acoustic pressure is applied. Additionally particle can be collected by changing vibration mode even though maximum acoustic pressure is not changed.
\end{abstract}




\section{研究背景と目的}

平板上に粒子を均一に散布し, その平板に超 音波振動を与える事で粒子が板振動の節の部分 へ集まる事が分かっている（Kofu K. et al., 2009）. 同様に空気中に超音波振動により定在 波音場を形成することで，気相中に分散してい る粒子を一点に集めることができることも分 かっている（Haake A. et al., 2005）。このような 超音波振動による粒子挙動を応用できれば, 様々な問題の解決やその他の技術に活用でき る。一つの例として, 集塵への応用が考えられ る. 現在の主な集塵方法としてフィルタを用い た集塵が挙げられる。しかし, フィル夕に堆積 した粒子の定期的な清掃, フィルタの目詰まり などの問題がある。また微小粒子の場合, 網間 を粒子が通過する可能性がある，超音波により 微小粒子を任意の位置に集中, 凝集させること ができれば捕集しやすくなり, 集塵効率の向上, または重力落下を利用したフィルタレスでの集 塵が期待できる。また，微小粒子だけではなく DNA や細胞などのハンドリングへも応用でき, 非接触の操作をすることで構造を傷つけること なく捕集や回収等が期待される（Morgan J. et al., 2004).

一方，空気輸送で粒子を搬送する際，パイプ の壁面に粒子が接触することによる粒子破損や 管内壁摩耗，壁面摩擦による輸送効率の低下等 の問題がある。また，生産工程に掞いて粒子飛 散は粉体ハンドリングにおける問題の一つであ る。そこで超音波振動により粒子挙動を制御す ることで，管内を浮遊している粒子の壁面接触 防止や定在波音場による粉体の飛散防止効果が 期待できる。

しかし, 超音波振動による粒子挙動制御の研 究はあまりされていない。 そのため, 超音波に よる最適な粒子ハンドリング条件は扔ろか, 粒 子種類や定在波音場の形成条件による粒子挙動 の相違は明らかにされていない，粒子を用いて 様々な条件での実験を行うには多大なコスト， 時間が要求される，超音波による粒子挙動への
影響に関する計算が可能になれば実験行程の短 縮，コストの削減並びに最適条件の提案が可能 になる。しかしながら，計算のみではその結果 の妥当性を証明することは難しい. そこで本研 究では, 空気中での超音波定在波音圧場内の粒 子挙動を実験で確認すると共に, 計算を行う. また, 粒子や最大音圧等を変更し, 各因子によ る変化を比較することで, 粒子挙動制御のため の最適条件の検討を行う.

\section{1. 計算方法}

\section{1 放射圧}

流体中に放射された超音波を物でさえぎる と, 超音波はその物を音の進行方向に押す力が 生じる。これを音響放射力という（Miura H., 1991）。定在波音場中で半径 $a$ の球状粒子に働 く音響放射力は， $a$ が波長に比べて十分に小さ い場合に式（1）で与えられる.

$$
\begin{aligned}
& \overline{F_{a c}}=V_{\mathrm{p}}\left(D \nabla \overline{e_{\mathrm{k}}}-(1-\gamma) \nabla \overline{e_{\mathrm{p}}}\right) \\
& {\left[D=\frac{3\left(\rho_{\mathrm{p}}-\rho_{0}\right)}{2\left(\rho_{\mathrm{p}}+\rho_{0}\right)} \quad \overline{e_{\mathrm{p}}}=\frac{\overline{p_{a}^{2}}}{2 \rho_{0} c_{0}^{2}} \quad \overline{e_{\mathrm{k}}}=\frac{\rho_{0} \overline{v_{a}^{2}}}{2}\right]}
\end{aligned}
$$

ここで $V_{\mathrm{p}}\left(=4 \pi a^{3} / 3\right)$ は球体積, $\gamma$ は球と媒質（空 気）の圧縮率の比， $\rho_{\mathrm{p}}, \rho_{0}$ はそれぞれ球と媒質 の変動前密度を示す。 $\overline{e_{\mathrm{k}}}$ は運動エネルギーの時 間平均值の傾き, $\overline{e_{\mathrm{p}}}$ はポテンシャルエネルギー の時間平均值の傾きを表す。 $D \nabla \overline{e_{\mathrm{k}}}-(1-\gamma) \nabla \overline{e_{\mathrm{p}}}$ は力学的ポテンシャルと呼ばれ, 単位体積あた りのエネルギーを表す。これを時間平均化した とき, 定在波の節の位置で最小となるため, 工 ネルギーの差により粒子が節に集中する。

\section{2 数值解析}

すべての流れについて質量と運動量の保存式 を解いており，伝熱や圧縮性を伴う流れについ てはエネルギーの保存式を追加して解く.また, 流れが乱流のため, 追加的に輸送方程式を解く. 計算手法として有限体積法を用いるため，まず コントロールボリュームで領域を分割する。微 
Table 1 Air properties

\begin{tabular}{|c|c|}
\hline Domain fluid & Compressible air \\
\hline Viscous model & $\begin{array}{c}\text { Large Eddy Simulation } \\
\text { (LES) }\end{array}$ \\
\hline Specific heat $[\mathrm{J} / \mathrm{kg} \cdot \mathrm{K}]$ & 1006.43 \\
\hline $\begin{array}{c}\text { Thermal conductivity } \\
{[\mathrm{W} / \mathrm{m} \cdot \mathrm{K}]}\end{array}$ & 0.0242 \\
\hline Viscosity $[\mathrm{kg} / \mathrm{m} \cdot \mathrm{s}]$ & Sutherland's law \\
\hline Temperature $[\mathrm{K}]$ & 300 \\
\hline
\end{tabular}

分方程式をコントロールボリューム $\Omega_{\mathrm{CV}}$ で積 分し, ガウスの発散定理を適用したものを式(2) に示す。

$$
\begin{aligned}
& \int_{\Omega_{\mathrm{cv}}} \frac{\partial \rho \varphi}{\rho t} \mathrm{~d} \Omega=-\int_{A_{\mathrm{cv}}} \rho \varphi \vec{V} \cdot \vec{n} \mathrm{~d} A \\
& \quad+\int_{A_{\mathrm{cv}}} \Gamma(\operatorname{grad} \varphi) \cdot \vec{n} \mathrm{~d} A+\int_{\Omega_{\mathrm{cv}}} S \mathrm{~d} \Omega
\end{aligned}
$$

この積分領域内の圧力や速度, 温度などの各 物理量の保存が満足される。式（2）のように, 各コントロールボリュームに線形代数方程式が 構成され，反復計算あるいは一度に解かれる。

$$
\begin{aligned}
& \frac{\rho_{\mathrm{p}} \varphi_{\mathrm{p}}(t+\Delta \mathrm{t})-\rho_{\mathrm{p}} \varphi_{\mathrm{p}}(t)}{\Delta \mathrm{t}} \Delta \Omega \\
& =-\sum_{j=1,2,3}(\rho \varphi \cdot \vec{V} \cdot \vec{n} \Delta A)_{\text {face } P-j}+\mathrm{L}
\end{aligned}
$$

計算条件の概要を表 1 および図 1 に示す。

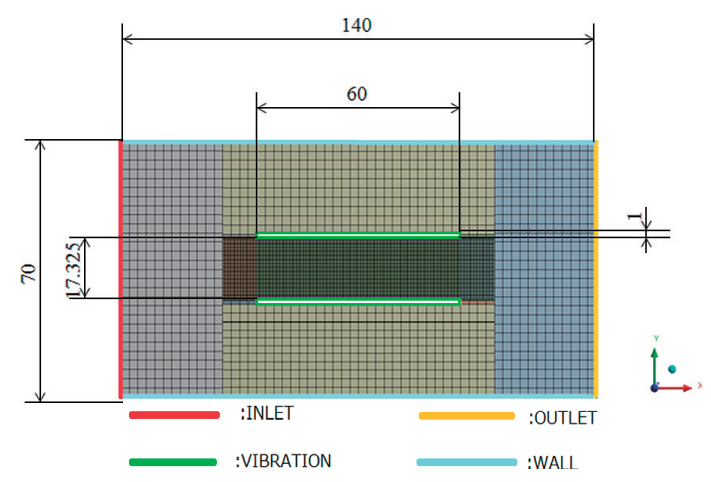

Fig. 1 Calculation area vibration, wall と名付けた境界は流体や粒子が 流出することのない壁であり，材質にはアルミ ニウムを用いた。片方の板のみを振動させた計 算では，安定した定在波を発生させることが難 しかったため, 今回計算では両方の板を振動さ せる、Vibration と記した境界をたわみ振動の腹 の数を変更して二次元定在波振動させ計算す る。なお，振動モードの定在波は式（4）で与 える。

$$
\Delta y=A_{\mathrm{m}} \sin (2 \pi f t) \cdot \sin \left(\frac{2 \pi}{\lambda} x\right)
$$

$A_{\mathrm{m}}$ は振動板の最大振幅, $t$ は時間, $\lambda$ は板の 長手方向に対するたわみ振動の波長である。な お, 板の主流方向に振動の腹の数 $N$ が 3 個現 われる振動モードとして,はじめ計算を行った。 本研究では振動板の長さが $60 \mathrm{~mm}$ であるため, $N=3$ では主流方向に $20 \mathrm{~mm}$ 間隔で振動の節が 現れることになる。

また，赤色で示した inletから流体を風速 $0.5 \mathrm{~m} / \mathrm{s}$ で流入し, 黄色で示した outlet から流出 する。板間隔は実験と同様，定在波の節が $2 つ$ になるように $17.325 \mathrm{~mm}$ とした，投入する粒子 は図 1 に示す板間の左端において $y$ 軸方向に等 間隔に9つ配置した。また，音響解析には非常 に細かいメッシュが必要であり, 定在波を計算 するため板間ではメッシュを細かく生成する. しかし，計算負荷を考慮すると，精度が十分で ある最低限のメッシュサイズを使用するべきで ある。そこで, 本研究では板間のメッシュサイ ズを $0.4 \times 0.4 \times 1$ で粒子挙動計算を行った.

\section{2. 可視化実験方法}

超音波発生装置を図 2 に示す。実験で用いた 装置は図に示すように発振器, 電圧増幅器, 超 音波振動子，共振棒，振動板から構成される. 発振器において電圧及び周波数 $f$ を設定し, 電 圧増幅器で入力電圧 $v_{0}$ が増幅される。増幅さ れた電圧は超音波振動子に入力され，振動子内 の圧電素子が微小変形することで, 発振器周波 数 $f$ の振動周期で振動する. 振動子の振動は工 


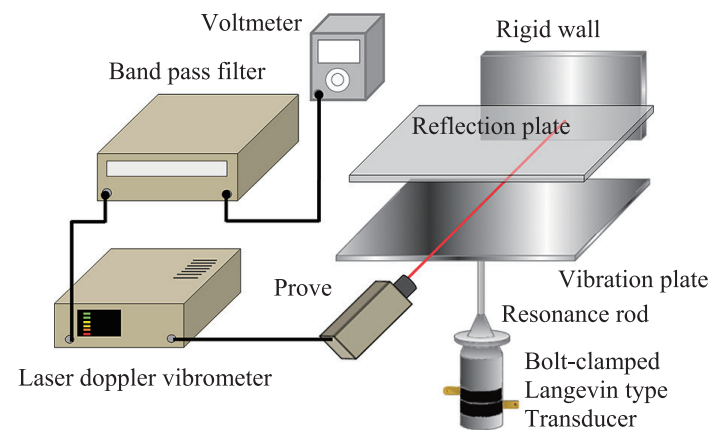

Fig. 2 Experimental apparatus for acoustic pressure

クスポネンシャルホーンに伝わることで増幅さ れ, 共振棒から振動板に伝わる. 振動子の振動 が振動板に伝わることで平板が周波数 $f$ の周期 で微小振動し, 空気中で空気密度の粗密変化が 生じることで超音波が放射される。

通常，局所的な音圧測定はマイクロフォンを 用いて行うが, 今回は板間隔が小さいために測 定点を十分に取ることができなかった。また， マイクロフォン自体が音圧分布を乱すことも考 えられるため，LDVのレーザを板間に図のよ うに照射し，レーザの屈折を利用することで音 圧分布を測定する（Nakamura K., 2001）。振動 板と垂直方向に $1 \mathrm{~mm}$ ずつ, 振動板と平行の方 向に $2 \mathrm{~mm}$ ずつ動かした，なお，本測定前に板 間隔を $27 \mathrm{~mm}$ として超音波振動を与え，1/4 イ ンチマイクロホンに内径 $1 \mathrm{~mm}$ のプローブ チューブを取り付けて局所的に測定した音圧分 布とLDVによる測定結果を比較し，LDVによ る測定值の妥当性を確認した，可視化実験装置 概略図を図 3 に示す，振動板に $f=20.5 \mathrm{kHz}$ の

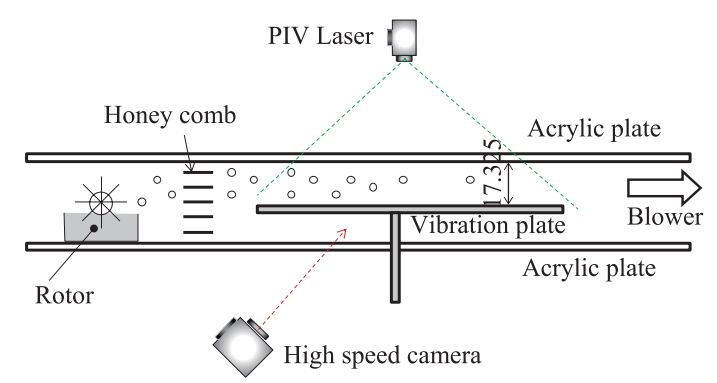

Fig. 3 Experimental apparatus for particle motion
超音波振動を与え, 定在波音場中に粒子を投入 し粒子挙動を観察する。容器に入れた粒子を モータにより拡散し, ブロワで吸引することに より板間に粒子を投入する，実験装置の真上か ら垂直に YVO4 レーザを照射することにより 可視化し, 板間の粒子を高速度カメラで撮影す る. 撮影した粒子挙動をPTVにより分析する。

\section{3. 研究結果および考察}

\section{1 音圧分布}

振動板間に発生させた音圧分布に関して, LDV を用いて測定した結果を図 4 (a), 解析で 再現したものを図 4（b）に示す。なお, 図 4 は $N=3$ となる振動モードで実験ならびに計算 した結果である。図 4 より, 計算值・実験值と もに設定通り板間の鉛直方向に節が 2 つある音 圧分布となっており，定在波が生じていること が分かる. また，水平方向に板のたわみ振動振 幅の大きい位置で音圧值が大きくなっており， 節の位置で音圧に変化がないことが分かる. 故 に, 板の表面変動により空気が圧縮されるため, 振動モードに応じて音圧值が高くなることが分 かり，たわみ振動のモード設定により音圧分布 を調整できると言える。また，音圧分布に関し て実験と解析で同様の分布となっており, 計算 により音圧分布を予測することができると言 える。

\section{2 粒子挙動}

本実験装置の最大音圧 $630 \mathrm{~Pa}$ を与えたとき の粒子挙動実験および計算結果を図 5 に示す。 なお，面奥行き方向に移動した粒子はシート光

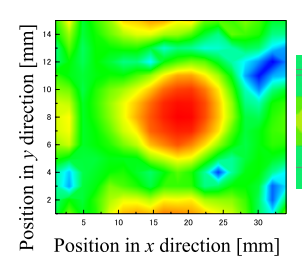

(a) Experiment

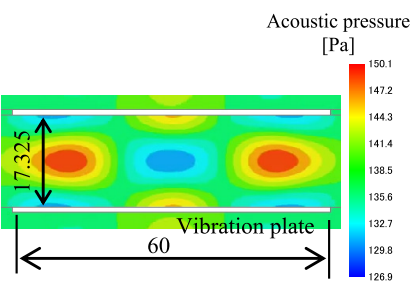

(b) Simulation
Fig. 4 Acoustic pressure distribution 


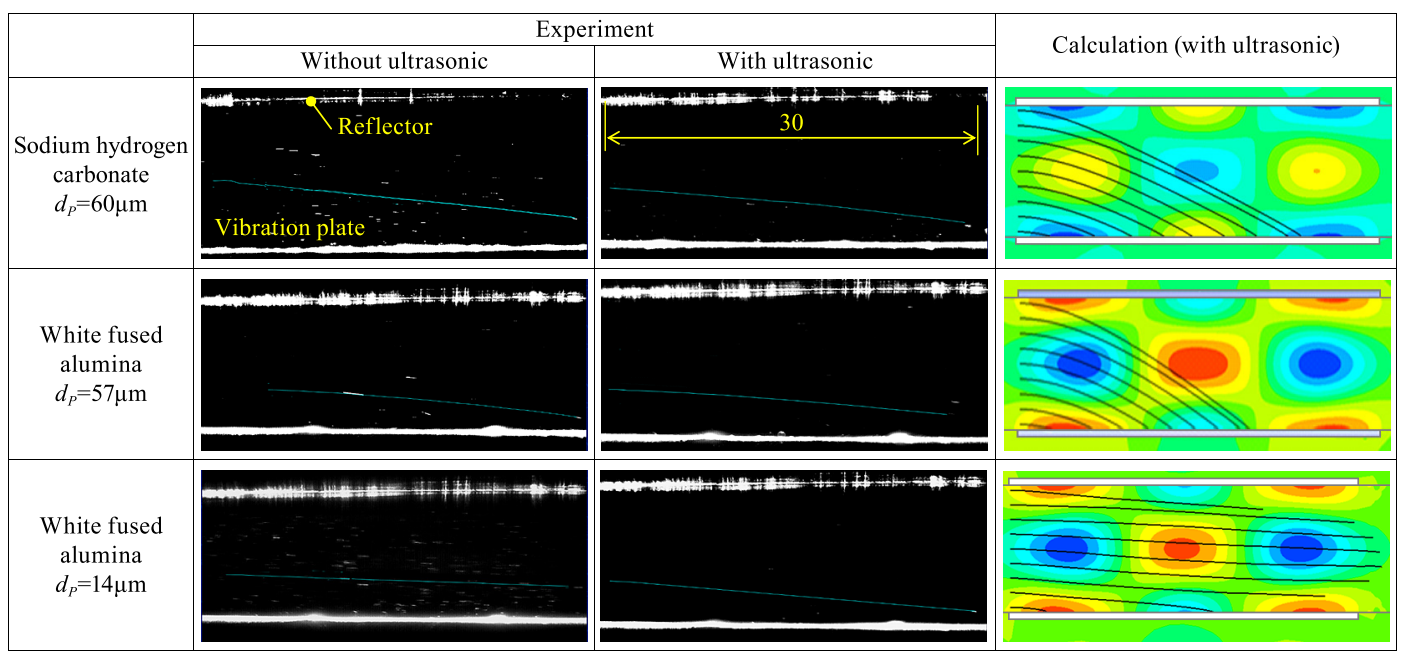

Fig. 5 Particle motion for ultrasonic vibration

源から外れ挙動分析できなかったため，画面左 から右端まで分析できた粒子軌跡のみを示す。 粒子径 $d_{\mathrm{P}}=60 \mu \mathrm{m}$ の炭酸水素ナトリウムと $d_{\mathrm{P}}=57$ および $14 \mu \mathrm{m}$ の白色溶融アルミナは超 音波振動有無に関わらず，実験值・計算值とも に重力により落下しており，定在波音場の節の 位置に捕集できないことが分かる。つまり，超 音波による放射圧が不足であり重力の方が大き いため, 超音波により挙動制御できないと言え る。一方, $d_{\mathrm{P}}=8 \mu \mathrm{m}$ の白色溶融アルミナでは 多少重力により落下しているが，ほぼ水平に動 いていること, ならびに上記同様に超音波振動 有無に関わらず挙動に変化がほほ生じていない ことが分かる。これは前述の音圧不足に加えて， 粒子径の影響が考えられる。粒子径が小さいと 質量が小さく重力の影響が小さくなり気流とと もに水平方向に動くことになる，超音波定在波 音場を通過するとき，式（1）の通り粒子が受 けられる放射圧が小さくなるため，超音波によ り挙動制御がし難くなり，結果として粒子軌跡 に変化が見られなかったと言える。次に， $d_{\mathrm{P}}=60 \mu \mathrm{m}$ の炭酸水素ナトリウムにおいて, 音 圧を $2000 \mathrm{~Pa}$ へ高めた計算結果を図 6 に示す。 この図も同様に，重力により落下しており，音 圧分布の節の位置に粒子を留め, 凝集させ捕集 することは $2000 \mathrm{~Pa}$ に音圧を高めても本超音波 定在波音場ならびに本粒子では難しいことが言

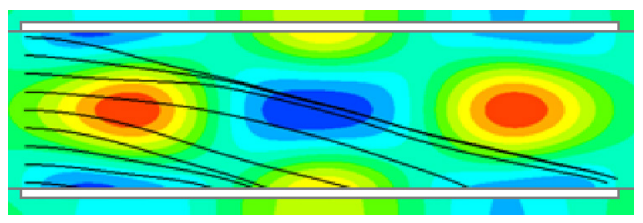

Fig. 6 Particle motion for ultrasonic vibration (Sodium hydrogen carbonate, $d_{\mathrm{P}}=60 \mu \mathrm{m}, P_{\max }=2 \mathrm{kPa}$ )

える。しかし音圧分布の腹の位置において， $630 \mathrm{~Pa}$ の結果と比べて粒子が落下する過程で軌 跡に変化が生じていることが分かる，故に音圧 を高めることで超音波により気相中の粒子挙動 をある程度制御できると言える。

以上の結果より, 超音波振動により粒子挙動 を変えられることが分かった。しかしながら， 本実験に用いた粒子の場合，粒子径が大きく重 力の影響が支配的となり, 超音波定在波音場に よる粒子挙動変化が分かり難い。 そこで, 図 3 に示す装置を 90 度回転させ, $d_{\mathrm{P}}=500 \mu \mathrm{m}$ の発 砲スチロールを鉛直上方から自由落下させ, 超 音波振動を与え空間に定在波音場を形成させた 時の粒子挙動について，シミュレーションと実 験結果を比較する。図 7 より発砲スチロールで は, 定在波の節の位置に動き集中している様子 がシミュレーション，実験共に確認できる。つ まり，重力と無関係な直角方向には $630 \mathrm{~Pa}$ 程 度の超音波定在波音場でも粒子を動かすことが でき, 無重力条件下などでは $630 \mathrm{~Pa}$ でも十分 


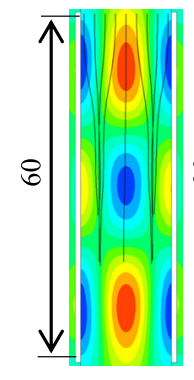

(a) Simulation (b) Experiment

Fig. 7 Particle motion (Styrofoam, $d_{\mathrm{P}}=500 \mu \mathrm{m}$ )
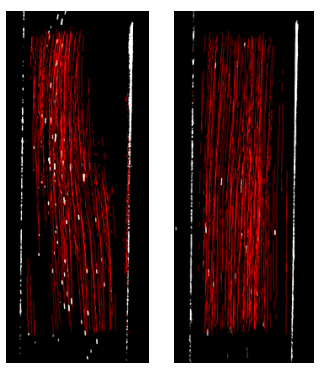

$\begin{array}{ll}\text { (a) } d_{\mathrm{P}}=8 \mu \mathrm{m} & \text { (b) } d_{\mathrm{P}}=57 \mu \mathrm{m}\end{array}$

Fig. 8 Particle motion (White fused alumina)

に粒子挙動を制御できることが分かる.同様に， $d_{\mathrm{P}}=8$ および $57 \mu \mathrm{m}$ の白色溶融アルミナを超音 波定在波音場中に自由落下させたときの軌跡を 図 8 に示す。図 8 より, 白色溶融アルミナにつ いては粒子径に関わらず多少粒子が動いている がその変化が小さく挙動制御が難しいことが分 かる，前述の通り粒子径が小さい場合，粒子が 受ける放射圧が小さくなるため，本実験装置に より生ずる音場条件では不十分であったため, 挙動変化が見られなかったと考えられる。また $d_{\mathrm{P}}=57 \mu \mathrm{m}$ ではほぼ主流方向のみに粒子が動い ているが, $d_{\mathrm{P}}=8 \mu \mathrm{m}$ では軌跡が板間で蛇行し ていることが分かる。これは音響流の影響と考 えられる。

図 9 に $d_{\mathrm{P}}=1 \mu \mathrm{m}$ の煙を流した時の可視化実 験結果を示す。この図より, 超音波振動を与え ていない時は一様に動いているが，超音波振動 を負荷すると流れが上下に蛇行していることが 分かる。 このように定在波音場が形成されるこ とにより板間に音響流が生じ，この流れにより 微小で軽い $d_{\mathrm{P}}=8 \mu \mathrm{m}$ の白色溶融アルミナが動

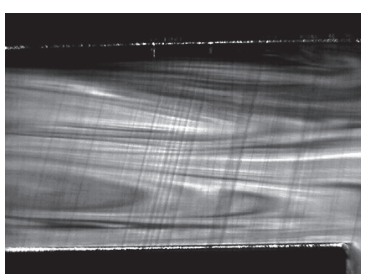

(a) Without ultrasonic vibration

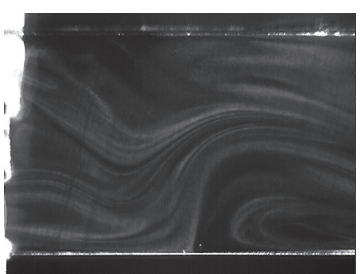

(b) With ultrasonic vibration
Fig. 9 Acoustic flow

かされたと考えられる，つまり，粒子径が大き い方が放射圧も大きくなり超音波定在波により 挙動を変化させることができるが， $50 \mu \mathrm{m}$ 程度 の粒子においては $630 \mathrm{~Pa}$ では重力の方が大き く放射圧が不十分であり，放射圧により粒子を 非接触で一点に集中させるには更に音圧を高め る必要があると言える。一方小さい粒子では, 放射圧では動き難いが質量が小さいため，音圧 分布により生ずる音響流を受け，挙動が変化す ると言える。そのため，粒子径により粒子挙動 に与える因子が変るため, 気相中の非接触粒子 ハンドリングには粒子径が大きい場合は重力と 超音波振動による放射圧, 粒子径が $10 \mu \mathrm{m}$ 程 度以下の小さい場合は音響流を考慮する必要が あると言える。

以上の結果より, たわみ振動の腹の数が 3 個 となり節間隔が $20 \mathrm{~mm}$ となる振動モードでは 超音波定在波により粒子軌跡を変化させること は可能であるが，一点に粒子を集中させる，ま たは気流中で保持することは難しいと言える. 一方，本研究においては計算值と実験值とが同 様の粒子挙動を示していることから, 定在波音 場における粒子挙動の計算が可能と言える。そ こで，最後にたわみ振動板の腹の数 $N$ を 3 個か ら 1 個へ変更したときの $d_{\mathrm{P}}=60 \mu \mathrm{m}$ における炭 酸水素ナトリウムの粒子挙動計算結果を図 10 に示す。なお本計算では, 最大音圧を $2000 \mathrm{~Pa}$ とし，また水平方向の流れで下方に重力を受け る条件で計算を行った， $N=3$ では図 6 の通り 重力により落下しているが, 図 10 の $N=1$ で は落下が抑えられ，鉛直方向の節の位置に粒子 を集め留めることができていることが分かる. 前述の通り，たわみ振動振幅の大きい箇所で音 


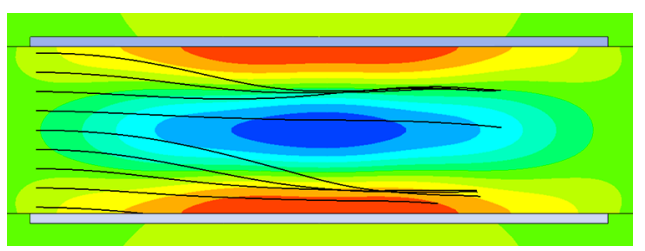

Fig. 10 Particle motion for ultrasonic vibration

(Sodium hydrogen carbonate, $d_{\mathrm{P}}=60 \mu \mathrm{m}, P_{\max }=2 \mathrm{kPa}$, $N=1)$

圧が大きくなり，この位置で粒子が放射圧を受 ける。主流方向に粒子が移動する中で, $N=1$ では長手方向に音圧の節がなく, 長く大きな放 射圧を受けることができるため, 最大音圧を更 に高めなくても粒子を板間の節の位置に移動さ せることができたと言える。つまり，音圧最大 值以外にもたわみ振動モードを変えることで, 効果的に粒子挙動を制御できると言える.一方, 図 6 において計算結果では音圧の高い位置で粒 子が徐々に節の位置へ動いている様子が見られ る。つまり, 主流方向に動くにつれて細かく粒 子挙動を制御したい場合にはたわみ振動板の節

\section{外部発表成果}

\section{口頭・ポスター発表}

1. 鈴木 熙, 劉 昕舜, 河府賢治：超音波定在 波による粒子挙動への影響, 2015 年度粉体
間隔を狭くし，音圧を高める必要があると言え る。一方, 細かい挙動制御が不要で小さい振動 振幅で節の位置に集めたい場合は，節間隔を広 くすると良いと言える。

\section{参考文献}

[1] Kofu K., Ochi M., Takei M., Hirai Y., Influence of particle properties on friction reduction of particle mass by ultrasonic, J. Soc. Powder Technol., Japan, 46 (2009) 330-337

[2] Haake, A., Neild A., Kim D.H., Ihm J. E., Sun Y., Dual J., Ju B.K., Manipulation of cells using an ultrasonic pressure field, Ultrasound in Med. \& Biol., 31 (2005) 857-864

[3] Morgan J., et al., Manipulation of in vitro toxicant sensors in an ultrasonic standing wave., Toxicology in Vitro, 18 (2004) 115-120

[4] Miura, H., Radiation force in aerial intense standing wave field of two-dimensional distribution, J. Acoustical Soc. Japan, 47 (1991) 941-947

[5] Nakamura K., Measurements of high power ultrasound in the air through the modulation in the refractive index of air, Technical Report of IEICE US, 101 (2001) 1520

工学会春期研究発表会, S-13, pp. 82-83 (2015)

2. Xinshun LIU, Hikaru SUZUKI, Kenji KOFU: Control of particle motion by ultrasonic standing wave, 6th Asian Particle Technology Symposium (2015) 